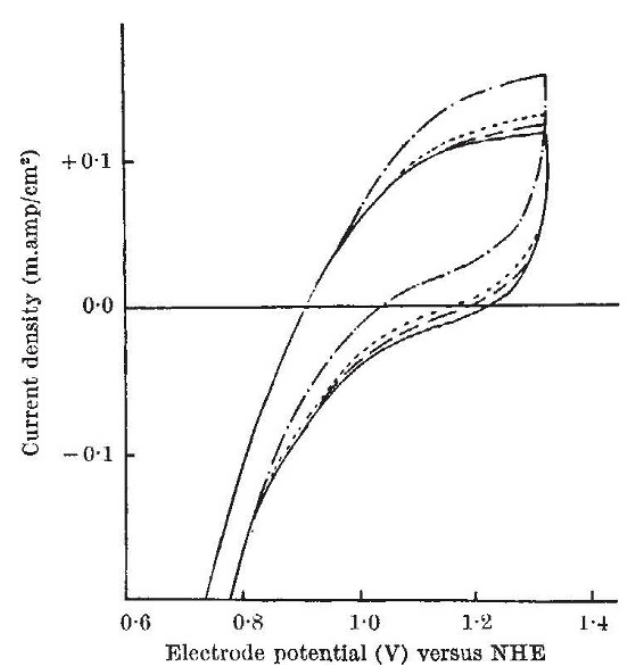

Fig. 2. Effect of hydrogen peroxide with oxygen-bubbled solution. $10 \times 10^{-5}$ mole $\mathrm{H}_{2} \mathrm{O}_{2} / \mathrm{l}$.

Now, the number of moles of oxygen reduced during one cycle can be calculated from the integral of the appropriate portion of the current-voltage or current-time curvo of Fig. 1 since the polarization varies linearly with timo. This quantity is oquivalent to 13 millicoulombs per $\mathrm{cm}^{2}$ or oqual to $2.3 \times 10^{-7}$ mole for tho $3.4 \mathrm{~cm}^{2}$ eloctrodo. Therefore, the curront of oxidation above $1.0 \mathrm{~V}$ would increaso in a moasurable way if only 1 per cent of this amount of oxygen was converted in $\mathrm{H}_{2} \mathrm{O}_{2}$ provided that these $\mathrm{H}_{2} \mathrm{O}_{2}$ molecules remain adsorbed on the electrode during the following anodic sweop. Even if the $\mathrm{H}_{2} \mathrm{O}_{2}$ molecules were instantaneously released from the electrode, the covorago would never reach 50 per cent of the surface during the cathodic sweep. Otherwise the concontration of hydrogen peroxide liberated in the $10-\mathrm{ml}$. solution of the working compartment would reach $1 \times 10^{-5}$ mole and could be detected by the increase in oxidation current above $1.0 \mathrm{~V}$.

The described experiments suggost that hydrogen peroxide is not formod as an intermediate product of the reduction of oxygen in acid solution at tho platinum olectrode. Hydrogen poroxide observed in other experimental conditions appears most probably as a sideproduct of roduction of oxygen. Consequently, hydrogen poroxide formation cannot be hold responsible for the overpotential of the oxygen electrode in an acidic fuel cell.

Furthermore, the foregoing experimonts confirm the hypothesis of Broiter ${ }^{6}$ that the reduction of oxygon proceeds only at the contact of bare platinum atoms since the reduction proceeds during the cathodic sweep only after approximately on $)$-quarter of the monolayor of platinum oxide has already been removed from the surface. The importance of the surface which must be cleared from the monolayor of platinum oxide bofore the reduction of oxygon occurs suggests, furthermore, that this catalytic reaction proceeds only aftor a molecule of oxygen has been adsorbed by two adjacent straight platinum atoms.

Charles C. Liang

West Virginia Institute of Tochnology,

Montgomory, West Virginia.

ANIRE L. JULIARD

Houdry Process and Chemical Co., Linwood, Pennsylvania.

1 Glasstone, S., and Hickling, A., Chem. Rev., 25, 407 (1939).

${ }^{2}$ Bockris, J. O'M., and Huq, A. K. M. S., P'roc. Roy. Soc., A, 237, 277 (1956)

${ }^{3}$ Hoar, J. P., J. Electrochem. Soc., 109, 858 (1962).

${ }^{4}$ Juliard, A. T., and Shalit, H., J. Electrochem. Sor., 110, 1002 (1963).

"Will, F. G., and Knorr, C. $\Lambda ., Z$. Elektrochem., 64, 258 (1960).

${ }^{6}$ Breiter, N. W., Electrochem. Actu, 9, 441 (1964).

\section{Reaction of Pentafluoroaniline with Boron Tribromide}

THe reactions between boron halides and amines hevo been examined extensively ${ }^{1-5}$. In theory, it is possible to substitute successively the halogen atoms in a boron halide to form the derivative $\mathrm{B}(R \mathrm{NH})_{3}$ from a primary amine, and the derivative $\mathrm{B}\left(R_{2} N\right)_{3}$ from the secondary amine. Alternative reaction schemes are possible, and in practice, if the amine is not in large excoss, the final product from a primary amine is usually a borazine.

$$
\begin{aligned}
\mathrm{BX}_{3}+R \mathrm{NH}_{2} \rightarrow X_{3} \mathrm{~B}-\stackrel{+}{\mathrm{N}} \mathrm{H}_{2} R \stackrel{(-\mathrm{H} X)}{\longrightarrow} X_{2} \mathrm{~B}-\mathrm{NH} R \\
\mathrm{II} \\
\stackrel{(-\mathrm{H} X)}{\longrightarrow}(X \mathrm{BN} R)_{3} \\
\mathrm{III}
\end{aligned}
$$

Intermediates of type II are unstable though their existence has been inferred, but those of type $I$ have been isolated. With the secondary amines, the reaction stops at the second stage, and compounds such as $\left(\mathrm{CH}_{3}\right)_{2} \mathrm{NBBr}_{2}$ are well known both as simple monomers and as dimers with four-membered boron-nitrogen rings ${ }^{6}$.

We find that approximatcly equimolar amounts of pentafluoroaniline and boron tribromide roact at $25^{\circ}$ with the evolution of hydrogen bromide and the formation of a solid mixture. At $50^{\circ}$ the mixture melts, more hydrogun bromide is evolved, and a colourless liquid remains. This is pentafluoroanilinoboron dibromido, $\mathrm{C}_{6} \mathrm{~F}_{5} \mathrm{NHBBr}_{2}$ (found: $\mathrm{B}, 2.9 ; \mathrm{Br}, 45 \cdot 2 ; \mathrm{C}_{6} \mathrm{~F}_{5} \mathrm{NHBBr}_{2}$ requires $\mathrm{B}, 3 \cdot 1 ; \mathrm{Br}, 45 \cdot 4$ per cent). The compound melts at $23^{\circ}$ and distils un. changed at $40^{\circ}-50^{\circ}$. It is moisture sensitive and is decomposed by water to boric acid, hydrogen bromide, and pentafluoroaniline.

At $70^{\circ}$ pentafluoroanilinoboron dibromide decomposes quickly, with the evolution of hydrogen bromide, to a white, crystalline solid which melts at $118^{\circ}-120^{\circ}$, and has a composition close to $\mathrm{C}_{6} \mathrm{~F}_{5} \mathrm{NBBr}$ (found: $\mathrm{B}, 3 \cdot 2 ; \mathrm{Br}$, $26 \cdot 3$; calc. for $\mathrm{C}_{6} \mathrm{~F}_{5} \mathrm{NBBr}$ : $\mathrm{B}, 3 \cdot 9 ; \mathrm{Br}, 29 \cdot 4$ per cent). The infra-red spcctrum of this material shows a weak absorption at $3,425 \mathrm{~cm}^{-1}$ in the position of the strong $\mathrm{N}-\mathrm{H}$ frequency of the dibromide, which suggests that this is the contaminant. There is also a strong absorption, nearly absent in the dibromide, at $1,380 \mathrm{~cm}^{-1}$, which lies in the region $\left(1,300-1,490 \mathrm{~cm}^{-1}\right)$ expected for boron nitrogen ring vibrations in borazines? proved possible to remove the contaminant from the material, which is almost certainly tris- $N$-pentafluorophenyltribromoborazine.

In bonzene, pentafluoroaniline reacts with boron tribromide at $10^{\circ}$ to give a crystalline adduct which appears to be the addition complex $\mathrm{Br}_{3} \overrightarrow{\mathrm{B}}-\stackrel{+}{\mathrm{N}} \mathrm{H}_{2}\left(\mathrm{C}_{6} \mathrm{~F}_{5}\right)$.

Pentafluoroanilinoboron dibromide is the first examplo of a type II intermediate to be actually isolated from the reaction betwoen a primary amino and a boron halide. Its reactivity and physical appearance suggest that it is monomeric, as the dimeric dihalides are air-stable solids. On standing, specimens appear to form the borazine slowly even at room temperature, so it is unlikely that the dimer will ever be isolated in a pure state.

\section{S. V. NAYAR}

R. D. PeACOCK

Department of Chemistry,

University of Birmingham.

'Johnson, A. R., J. Phys. Chem.,16, 1 (1912).

${ }^{2} J$ ones, R. G., and Kinney, C. R., J. Amer. Chem. Soc, 61, 1378 (1939).

${ }^{3}$ Henry, M. C., Hazel, J. F., and McNabb, W. M., Anal. Chim. Acta, 15, 187 (1956).
usgrave, O. C., J. Chem. Soc., 4305 (1958).

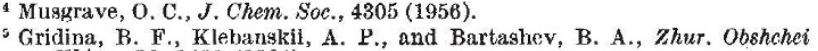
Khim., 34, 1401 (1964).

- Banister, A. J., Greenwood, N. N., Straughan, B. P., and Walker, J., J. Chem. Soc., 995 (1964).

'Gerrard, W., The Organic Chemistry of Boron, 230 (Academic Press, London, 1961). 